This is a self-archived version of an original article. This version may differ from the original in pagination and typographic details.

Author(s): Tynjälä, Päivi; Pennanen, Matti; Markkanen, Ilona; Heikkinen, Hannu L. T.

Title: Finnish model of peer-group mentoring : review of research

Year: 2021

Version: Accepted version (Final draft)

Copyright: (c) 2019 New York Academy of Sciences

Rights: In Copyright

Rights url: http://rightsstatements.org/page/InC/1.0/?language=en

Please cite the original version:

Tynjälä, P., Pennanen, M., Markkanen, I., \& Heikkinen, H. L. T. (2021). Finnish model of peergroup mentoring : review of research. Annals of the New York Academy of Sciences, 1483(1), 208-223. https://doi.org/10.1111/nyas.14296 
Finnish Model of Peer-Group Mentoring: Review of Research

Päivi Tynjälä${ }^{1}$, Matti Pennanen ${ }^{1}$, llona Markkanen ${ }^{1} \&$ Hannu L.T. Heikkinen $^{1}$

${ }^{1}$ Finnish Institute for Educational Research, University of Jyväskylä, Finland

\section{Corresponding contact:}

Päivi Tynjälä, Finnish Institute for Educational Research, University of Jyväskylä, 40014 Jyväskylä, Finland. Phone: +358 50400 9464. Email: paivi.tynjala@jyu.fi

Short title: Finnish Model of Peer-Group Mentoring

Keywords: peer-group mentoring; mentoring; teacher development; professional development; Finland 


\title{
Finnish Model of Peer-Group Mentoring: Review of Research
}

\begin{abstract}
This article reviews research on the Finnish model of Peer-Group Mentoring (PGM). Theoretical foundation of the model is based on the constructivist theory of learning, concept of autonomy in teaching profession, peer learning and narrative identity work. The model has been disseminated nationwide on the educational sector to promote professional development of teachers and educational staff mainly in primary and secondary education, but also in early childhood education and higher education. The thematic review is based on 46 peer-reviewed publications about PGM in Finland in 200919. Research has focused on the following main themes: 1) general aspects and characteristics of the implementation of the model, and 2) mentors' and mentees' experiences. Qualitative approach has been dominant in research. The studies show that both mentors and mentees find PGM a useful tool for individual professional learning and well-being. Indirect influences have been reported about the development of work communities. Main challenges in applying the model are lack of national agreement concerning the organization of PGM and allocation of mentors' and mentees' working time to PGM. It is concluded that PGM as well as teachers' professional development as a whole should be seen as an integral part of the education ecosystem.
\end{abstract}

\section{Introduction}

Mentoring has been globally used as a method of professional development in teaching as well as in other fields. Traditionally mentoring has taken place in pairs, with an idea of an experienced professional transmitting knowledge to a less experienced colleague. ${ }^{1,2}$ Recently, along with the ideas of collaborative learning and professional learning communities, new group-based models called, for example, collaborative mentoring, group mentoring, peer-mentoring or peer-group mentoring have been developed. . $^{3,4,5,6 .}$ In this article we review research focusing on one of such group-based models, the Finnish model of Peer-Group Mentoring (PGM).

In the European context, the European Union provides recommendations and guiding documents for teachers' professional development. In order to tackle new teachers' attrition, EU has set the aim that beginning teachers are offered three types of support: professional, social and personal. ${ }^{7}$ Mentoring can be seen as a method involving potential for all these three forms. It is also stated that the mentoring relationship should be collegial and professional, instead of hierarchical. ${ }^{7,8}$ In Finland, young teacher attrition, a typical problem in many European countries and the USA, has been negligible. Qualification of teachers has required a master's degree in Finnish schools since 1979, and teacher education has been among the most popular choices for university applicants - with the consequence that only the best students get the study place. ${ }^{9}$ Because of the researchbased high level teacher education little attention has been paid to the induction phase support until recently. Current educational policy emphasizes the importance of seeing teachers' professional development as a seamless continuum throughout the teacher's 
career from initial teacher education to retirement. ${ }^{10}$ The Finnish model of PGM has been developed for serving this purpose. It provides a new model of mentoring, targeted not only for beginning teachers but teachers in any phase of their career.

The Finnish PGM model was originally developed and piloted through an action research project in 2007-09 by the Finnish Institute for Educational Research, in close collaboration with four education providers, and funded by the Finnish Work Environment Fund. The theoretical foundation of the model is based on the constructivist theory of learning, the concept of autonomy in teaching profession, peer learning, and narrative identity work. The leading pedagogical principle has been the model of integrative pedagogy, which aims at merging theoretical and practical knowledge with self-regulative and sociocultural knowledge ${ }^{6}$.

Since 2010 the PGM model has been disseminated nationwide on the educational sector through several consecutive projects funded by the Finnish Ministry of Education and Culture to promote professional development of teachers and educational staff mainly in primary and secondary education, but also increasingly in early childhood education, higher education, and liberal adult education. Training of mentors is organized by the Finnish Network for Peer-group Mentoring. The network consists of all Finnish teacher education institutions, including both teacher education departments of universities and vocational teacher education in universities of applied sciences. The main goal of the network is to develop and disseminate the PGM model to support professionals in the educational field. ${ }^{11}$

In the development of the PGM model key stakeholders in the field, The Trade Union of Education in Finland and The Local Government Employers, have been involved through their participation in the Steering Group of Network for Peer-Group Mentoring. Both of the unions stress the importance of teachers' professional development and collaboration between the stakeholders in educational sector in order to maintain teaching profession appealing and valued choice for future candidates, and to support sustainable development in educational sector. They also regard peer-group mentoring aligning well in the bigger picture of future development plans. ${ }^{12}$ In Finland, the education professionals, the wider community, and municipal and national education agencies are broadly agreed that mentoring as collaborative self-development is an appropriate form of mentoring. ${ }^{13}$

In practice, PGM is organized by education providers, usually municipalities. A peermentoring group typically has four to eight members who meet once a month during an academic year to discuss their everyday work and work-related challenges. The groups work autonomously, and the group members jointly agree on the topics they deal with, the schedule for the meetings, and the rules of the activity such as confidentiality of the discussions. The group meetings are facilitated by trained mentors who may use a variety of group work methods. ${ }^{14}$

In organising PGM, education providers have utilized a variety of models as regards the composition of groups. For example, participants of the groups may

- come from one school or different schools

- teach the same subject or different subjects

- be new teachers or teachers in different career phases 
- be in-service teachers only or in-service and pre-service teachers mixed

- get together not only in face-to-face meetings but also by social media tools.

During the years 2017-2019 new PGM applications and practices were experimented and implemented by several projects addressed to different groups such as student teachers, educational leaders and managers, multidisciplinary groups of early childhood educators, basic education and youth work, liberal adult education, educators interested in multicultural education and teachers in higher education. ${ }^{15}$ By 2019 approximately 900 mentors have been trained to 150 municipalities, and majority of the mentoring groups are from basic and secondary education. It is estimated that circa 2000 educational professionals are involved in PGM on yearly basis. However, the proportion of teachers participating to mentoring is still low. In the TALIS study (Teaching and Learning International Survey, p. 144-145) by OECD ${ }^{16}$ more than $60 \%$ of school leaders in Finland reported that they did not have a mentoring program for teachers in their school. Five per cent of teachers reported that they had an assigned mentor. Although the mentoring culture in Finnish education system is still quite young, the PGM model has attracted attention also in some other professional areas such as health care ${ }^{17}$, and librarians' professional development. ${ }^{18}$

The Finnish model of PGM differs by certain features from some other international mentoring models. In contrast to typical international models, PGM is developed for serving all teachers and education professionals, not only new teachers. The core of the activity is sharing knowledge and experiences and learning from each other, rather than transmitting knowledge from more experienced colleague to less experienced one. While in some international models the participation into mentoring for new teachers is compulsory and involves assessment of the mentee, in the Finnish model participation is voluntary and no assessment is involved. In the following sections we review on national and international research on the Finnish PGM model.

\section{Review Materials and Methods}

In our literature review we addressed the following questions:

1) What have been the main characteristics of implementation and dissemination of the Finnish PGM model?

2) How have mentors and mentees experienced participation in PGM?

3) What is the role of PGM in administrative structures of education?

\section{Literature search}

The literature was collected in two phases. First, the participants of the Finnish Network for Peer-group Mentoring were asked to report all the publications they have produced on the topic. As an outcome, a list of 193 publications was compiled. The list included seven edited books, 21 articles in peer-reviewed journals, 25 chapters in peer-reviewed edited books (or peer-reviewed conference proceedings), 53 chapters in non-refereed edited books, 21 master's theses, three doctoral dissertations and 69 conference papers or posters. There was some overlap between the publications. For example, doctoral dissertations consisted of published articles, and some peer-reviewed articles were based on master's thesis. Many 
non-refereed publications were also included into the list. In order to ensure the scientific quality of the material, we set the following criteria for the publications to be included in the review: 1) They had to be peer-reviewed, 2) They had to focus on peer-group mentoring instead of traditional one-to-one mentoring. However, studies comparing these mentoring models were included. 3) Studies had to be conducted in the Finnish context. Thus, we excluded master's theses and non-refereed articles, book chapters and conference papers. The final number of publications for the review consisted of 46 peer reviewed articles and book chapters. However, when clarifying practical information was needed, non-refereed publications were used as additional material. One of the journal articles was still in the review process when writing this article.

In the second phase, a systematic search of literature from ERIC database and the Finnish ARTO database was conducted to ensure that all relevant material was included into the review. The keywords "peer-group mentoring" in title and "Finland" in country field were used in the former database, and "vertaisryhmämentorointi" or "verme" (Finnish acronym for PGM) in the latter. The search from these databases did not produce any other peerreviewed publications by the members of the Finnish Network for Peer-group Mentoring than those which were already listed. One publication by researchers outside the Network was found ${ }^{17}$ but it focused on using the method in health care sector.

For the qualitative analysis, the studies were carefully read, and the following details of the studies were recorded into a spreadsheet: publication forum (international/national), the authors, the topic, educational level(s) and sector(s), research questions, data, analytic methods, main findings and notes (researchers' interpretation). In addition, the topics, analytic methods and findings were recorded. The main findings of the studies were summarized in short phrases such as "Mentees saw PGM as important tool for PD throughout the teaching career. Few significant differences between general and vocational teachers. New conceptualization of PD: development of skills and knowledge, strengthening professional identity, development of work community". In the next phase, the recorded data were carefully read to answer the research questions. In many cases the original studies were consulted.

\section{Results}

\section{Features of the included studies}

Of the final data of 46 publications 20 focused on PGM model in general education (including primary, secondary and general upper secondary education), five represented vocational education and training, and two higher education (including teacher education). In four studies the PGM was examined in more than one education level or sector. The rest 15 studies were theoretical or conceptual studies in nature. Methodologically, qualitative research approach was dominant, only in one study quantitative methods were used. The selected publications, their data collection and analytic methods, and participants are presented in Appendix 1. In the following sections we present the findings of the thematic review. First, we focus on research on the implementation and dissemination of the PGM model. Second, studies on experiences of mentees and mentors are reviewed, and third, 
studies related to the role of PGM in administrative structures of education are presented. Finally, the findings of the review and future perspectives are discussed.

\section{Characteristics of implementation and dissemination of the Finnish PGM model}

As to our first research question about the main characteristics of the implementention of the PGM model, two thematic lines of research were identified: studies focusing on different models of organizing mentoring, and studies aiming at identifying prerequisites and characteristics of successful mentoring.

\section{Different models of organizing mentoring}

In the early phases of the development of the PGM model Heikkinen, Jokinen and Tynjälä ${ }^{19}$ examined different options for organizing mentoring for teachers in Finland. The first mentoring experiments included three models: 1) traditional paired mentoring with one experienced mentor teacher and one novice teacher, 2) peer mentoring with an experienced teacher as a mentor and a group of beginning teachers, and 3) peer-group mentoring with an experienced mentor and a group consisting of both new teachers and experienced teachers. Thus, there were differences in goals and starting points of the models. The objective in the first two models was to support newly qualified teachers in the beginning of their careers, whereas the third model aimed to develop a new form of teachers' continuous professional development to benefit teachers at all stages of their careers.

The comparison of the three models found strengths and challenges in all models. Common to all models was that both the mentees and mentors found mentoring as a functional forum for professional dialogue and sharing experiences ${ }^{19}$. The one-to-one model made more personal discussions possible, whereas in the group models discussions brought about a bigger variety of different perspectives and new ideas on the topics dealt with. The study also showed that whatever model is used maintaining mentoring activities require well-defined structures, coordination and management from the local school administration. The lack of mentors was a problem in the paired mentoring model, while in the group models the required number of mentors is smaller. The lack of local or national agreements about organizing mentoring, compensations of mentors and allocation of working time of mentees proved to be problematic inasmuch as organizing the activities may then depend on individuals' motivation and are thus vulnerable when administrative officials change ${ }^{19}$.

As the PGM model emphasizes the autonomy of the teaching profession, no strict directions (except the principles described in the Introduction) are given for education providers on how to organize activities. Consequently, a variety of practical applications have been developed, and the model has proved to be flexible enough to be successfully applied for supporting specific groups of educational professionals, for example school principals and school assistants ${ }^{20}$, migrant teachers ${ }^{21}$, and teachers in small and rural schools. ${ }^{22}$ Furthermore, the model has been applied in some other professional areas such as health care. ${ }^{17} \mathrm{~A}$ variety of practical group work methods, such as narrative and activating methods ${ }^{23}$, dialogue cards ${ }^{24}$ and externalizing discussion ${ }^{25}$ have been developed to be used in parallel with conventional group discussions. According to Estola, Heikkinen and Syrjälä26 
narrative methodology has proved to be a promising tool for mentoring, both for preservice and in-service teachers.

The composition of groups may vary from quite homogenous to more heterogeneous ones. Several studies have focused on pros and cons of different solutions. In general, in heterogeneous groups sharing experiences and emergence of new ideas seem to be easier, whereas in homogeneous groups the development of sense of belonging takes less time. For example, in a study conducted in a multi-disciplinary mentoring group at a vocational school Ahokas ${ }^{27}$ found out that the multi-disciplinary approach was welcomed by the participants as it made it possible for them to share experiences and views with colleagues whom they would not otherwise meet. When teachers from various fields were involved the attention was focused on pedagogy rather than teaching contents. The teachers felt that the dialog with colleagues coming from other domain than their own helped them broaden their perspectives into their work. According to findings, multi-disciplinary composition of the group enriches discussions, but it can also create intra-group tensions. ${ }^{27}$

Lahdenmaa and Heikkinen ${ }^{28}$ examined PGM in homogenous and heterogeneous groups in terms of teachers' work communities (from the same school vs different schools), gender, and school level (elementary, primary, secondary). According to their analysis, the strength of a homogeneous group with teachers coming from the same work community was the communality that already existed due to the school's working culture. In contrast, the lack of communality was characteristic to the heterogeneous group whose members came from different schools and did not know each other. Thus, group formation took a considerable amount of time of group meetings. On the other hand, Ahokas ${ }^{27}$ has observed that "If the group includes too many mentees who have previously known each other there is a risk that discussion among them becomes too dominant.". In a study by Kaunisto, Uitto, Estola and Syrjälä ${ }^{29}$, the teachers found it important that the participants of the group came from different schools and that they did not know each other beforehand. This helped them in sharing their experiences of and emotions related to challenging situations.

In terms of teachers' experience, heterogeneous mentoring groups have also offered for inservice and pre-service teachers in mixed groups. ${ }^{30-32}$ In these studies the participants have found the mixed group solution fruitful for their learning. On the basis of their analysis Lahdenmaa and Heikkinen ${ }^{28}$ concluded that both homogeneous and heterogeneous groups have their strengths and weaknesses and that it is important to focus on goals when forming the groups. Similarly, in their study concerning new teachers' experiences, Estola, Syrjälä \& Maunu ${ }^{33}$ presented a hypothesis that "a suitable portion of similarity and diversity in group composition will bring additional value to the group".

Recently, different models of organizing PGM have been piloted for several professional groups in the education sector, and, in general, in these projects PGM has been regarded as a beneficial form for professional and organizational development. However, finding enough time for PGM in hectic working life is often a challenge that complicates commitment to the group's activities. Further issues to be resolved include the compensation of employees for their time in peer-group mentoring and finding financing models to establish the activity on a regular basis. ${ }^{15}$. It has been suggested that a national collective agreement about 
organizing PGM is needed to secure its status as an officially recognized form of teacher development. $^{34}$

\section{Characteristics and prerequisites of successful mentoring}

Altogether seven studies highligted the key factors for successful PGM. "Successful" here refers to positive experiences expressed by the participants, mentors and education providers and to the balance of equality and polyphony of experiences between group members. ${ }^{35}$ In their study Teerikorpi and Heikkinen ${ }^{36}$ asked mentors to write stories of successful and unsuccessful mentoring group. On the basis of their narrative analysis they identified several factors contributing to success or failure in PGM, and they could be divided into three main categories: 1) physical and administrative factors, 2) social factors and 3) methodological factors.

The physical factors include, for example, the space and time of PGM meetings. A cosy meeting room at school or outside with refreshments was seen important for creating a welcoming atmosphere. The administrative factors refer to organizational and municipal support for organizing PGM. In Finland, the education system is almost entirely public, and municipalities are education providers on primary and secondary levels. Thus, municipalities decide about financial support to mentoring, such as mentors' fees and place offered for the meetings. Municipalities have autonomy, and there are no national regulations about organizing mentoring, from which it follows that there is variation between municipalities in how much financial support is allocated to this purpose. Very recently, municipalities have cut funding for PGM. ${ }^{34}$ For this reason, calls for better recognition of peer learning as a form of professional development have been presented. ${ }^{34}$

The social factors contributing to successful group functioning are related to interaction in peer groups and attributes of the mentor and the group. For example, mentor's and mentees' motivation, mutual encouragement, and active listening of each other were regarded as making open and confidential environment for constructive discussions. ${ }^{36}$ The methodological factors refer to how the group operates and what is done during PGM sessions. These factors encompass the principles of the PGM activities on one hand and methods on structuring and organizing the meetings on the other hand. As regards to principles, it was seen important that the group members together agree about the common rules, time management, and themes to be discussed. As to methods of structuring the meetings and ways of working it was found that the participants appreciated relaxing start with introduction round, alternation between free and guided discussion, and the use of different group work methods. ${ }^{36}$ It is also notable that physical, administrative, social and methodological factors are intertwined. For example, engaging in a dialog about one's personal work experiences may cause discomfort and therefore it is regarded important for the success of peer group meetings that clear agreement about confidentiality and shared working principles such as respect and trust is made in the group. ${ }^{29,32}$

Based on PGM participants' perceptions, Pennanen, Heikkinen \& Tynjälä ${ }^{37}$ formed a conception of the preferred social interaction in peer-group mentoring meetings. In total sixteen characteristics were identified, which expressed proactive interaction, reactive and 
responsive interaction, and personal presence. The findings showed that in PGM the mentor's role was seen about facilitating the meeting (preparation, practical arrangements) and the discussion (guiding, asking questions) and that mentor was recognised as an equal member in the group. In PGM, participants share their knowledge and experiences, and sharing is valuable as such without any formal titles to highlight or prefigure the expertise. ${ }^{35}$

A study by Heikkinen et al. ${ }^{38}$ interrogated the forms of communication in mentoring practices. Study utilized a Habermasian notion of communicative action, which orientates towards mutual understanding (through free and reciprocal dialogue), and strategic action, which orientates towards pre-determined aims (through giving instructions or advices). The success in mentoring is about finding a balance of the communicative and strategic action and this twofold purpose and rationale highlights the complicated role of a mentor - the tensions between supporting versus judging, or being a mentor versus being an evaluator. ${ }^{38}$ Mentor can succeed in the task of mentoring by cultivating different kinds of discussions in the group that were identified as opening up, facilitating, counselling, guiding, and organizing.

\section{Mentors' and mentees' experiences of participation in PGM}

As regards our second research question about the mentors' and mentees' experiences of PGM, most of the studies have focused on mentees. In the following sections we first review studies of mentees' experiences in general and then experiences of new teachers and student teachers in particular. After this, studies focusing on mentors are presented.

\section{Mentees' experiences}

In general, teachers, whether new or experienced in their profession, have found PGM important for their professional development and wellbeing. ${ }^{29,33,39-40}$ For example, in a study by Geeraerts et al. ${ }^{39} 96 \%$ of the mentees participating in PGM found peer group mentoring important both at the beginning of teachers' working career and also in later stages of working life, and $84 \%$ of the respondents perceived that the other members of the group supported their professional development. On a personal dimension of support, $84 \%$ of the respondents felt that PGM had strengthened their professional identity. As to social dimension of professional development, $81 \%$ of them agreed with the statement that PGM had improved their collaboration skills. This study also compared vocational teachers and their colleagues in general education, and some significant differences were found. About $55 \%$ of vocational teachers reported that they had changed their working methods due to participating in PGM, whereas $35 \%$ of the general education teachers agreed with this statement. While $38 \%$ of vocational teachers reported that they had been contacted more often by their colleagues about their opinions and advice after participating the PGM, only $10 \%$ of general education teachers had noticed this kind of effect of their PGM experience.

As to the outcomes of participating in PGM, the quantitative study by Geeraerts et al. ${ }^{39}$ showed that the development of skills and knowledge was experienced as the strongest effect of the activities, and strengthening of professional identity was found the next 
important outcome. The effects on the development of work community were the weakest, and here vocational teachers experienced significantly stronger effects than their colleagues in general education. According to qualitative studies, PGM has provided vocational teachers with a place where they have had time to discuss and analyze their changing teacher identities and working cultures in the mid of reforms and change processes going on in the field of vocational education. ${ }^{27,41-42}$ This is experienced as a welcomed movement towards more collegial working in the environment traditionally characterized by strong individualistic working and learning culture. ${ }^{43,44}$

While the studies above mainly describe the outcomes of PGM activities, Kaunisto, Estola and Niemelä ${ }^{45}$ examined the mentoring process, group dynamics and group development in particular. In their analysis they applied Tuckman's ${ }^{46}$ classical description of stages of group development: forming, storming, norming, performing, and adjourning. They conclude that awareness of the group development is useful for mentors in order to find suitable methods in different situations. Research has also indicated that peer groups can contribute to the self-reflection process by supporting participants' self-understanding and offering more realistic views of one's professional options. ${ }^{47}$

The mentoring processes were in focus also in the study by Kaunisto, Uitto, Estola and Syrjälä ${ }^{29}$ who examined PGM as a forum providing a place for sharing emotionally challenging experiences of teachers. For this purpose the participants appreciated that they did not know each other beforehand, which made it easier for them to share their experiences of challenging situations. The authors concluded that teachers need peer groups where they can mutually share their experiences and emotions related to their work. Other studies have supported these findings, showing that both beginning teachers and experienced teachers find PGM contributing to their well-being by reducing stress, helping them handle problem situations and creating personal networks. ${ }^{48}$ Teachers have consistently reported that sharing experiences in a confidential group can be of crucial importance not only for well-being and copying with stress, but also for new perspectives and ideas to be applied to work. ${ }^{32}$ Teachers experience that PGM provides them with time for discussion that is not available during busy working time, and that the dialog helps them broaden their perspectives into their work, especially when the group consists of participants coming from different work communities and different fields. ${ }^{26,48}$ In higher education, teachers also have reported that through increasing collegiality the participation in PGM supports the development of educational programs. ${ }^{49}$

Some studies have examined participants' experiences of mixed PGM groups of pre-service and in-service teachers. In a study by Kiviniemi et al. ${ }^{30}$ thematic analysis of interviews with in-service teachers revealed four main themes of experiences: 1) enjoying group activities, 2) personal professional development, 3) attaching to the professional community, and 4) developing the teacher profession. While in the first theme teachers emphasized relaxation and unwinding, the second theme raised professional reflection and empowerment as benefits of PGM activities. The third theme focused on strengthening the sense of community, and the fourth theme revealed teachers' tendency to serve as a kind of teacher educator while helping student teachers in their professional growth. The researchers conclude that the mixed or 'hybrid' model of PGM contributes to teacher learning in ways which benefit not only teachers themselves but also schools and teacher education 
institutions. Similarly, Uitto et al. ${ }^{33}$ found mixed groups as a powerful learning sites in which pre-service and in-service teachers are given an opportunity to share their professional experiences, and recommend utilizing this type of learning in teacher education.

Most of the studies on PGM have been conducted on primary and secondary level of education. Onnismaa, Tahkokallio, Lipponen and Merivirta ${ }^{40}$ examined kindergarten teachers' experiences, and their findings are in line with the findings reported above. On the basis of the surveys it was found that the participants experienced peer group mentoring as a meaningful form of professional development. The study identified the following features of PGM as significant for the participants: peer support, confidentiality and openness, time and space for discussion, guidance and professional development, and strengthening of professional self-esteem and identity. The participants were also asked about possible missing things, and for this question many replied just "nothing was missing". Other comments referred to short duration of the mentoring, wishes of more structured working and stricter manner for the mentor, more positive manner, and more guidance and practical tips.

New teachers' and student teachers' perspective into peer-group mentoring

Although peer-group mentoring was developed to organize support for teachers in all stages of their career, a special attention has been paid to the induction phase. Therefore several studies investigate peer-group mentoring from new teachers' perspective. In their international review on beginning teachers' transition from education to working life Tynjälä and Heikkinen ${ }^{50}$ identified several challenges new teachers meet, such as inadequate knowledge and skills, decreased self-efficacy and increased stress, early attrition, newcomers' role and position in a work community, and importance of learning at work. In PGM meetings new teachers have an opportunity to discuss these challenges with their colleagues, either by new teachers themselves or with more experienced ones. Generally, in Finland, newly graduated teachers are well prepared in the research based in-service teacher education. ${ }^{9,}{ }^{51}$ However, many of the challenges listed above are encountered by new teachers when entering working life, and these experiences seem to appear not only in the classroom arena but also in wider school arena. ${ }^{52-53}$ Thus, several studies emphasize the importance of good social atmosphere with genuine concern and caring amongst the members of the school community, in order to support new teachers' induction. ${ }^{52-54} \mathrm{New}$ teachers face with the complexity of the work also outside the classroom. For example, relations with parents are often raised as a challenging issue in PGM meetings. ${ }^{28,55}$

As a response to the observed need of bridging teacher education, induction support, and continuous in-service professional development ${ }^{10,56-57}$, peer-group mentoring has recently been also implemented in teacher education, in order to combine teacher students and inservice teachers in the same groups. In some cases, soon-to-graduate student teachers have participated in an optional PGM course lead by an experienced in-service teacher ${ }^{29,58}$ whereas in some cases student teachers and in-service teachers as mentees have formed mixed peer groups ${ }^{29-31}$ The results have been mainly positive and beneficial to both student teachers and teachers in working life. Main challenges are related to different expectations, commitment and obtained roles in the group activity. ${ }^{31}$ Heikkinen ${ }^{59}$ argues that in terms of teacher education in its pure sense, the aim of PGM is to support professional learning and 
well-being at work by promoting teachers' autonomous professional agency, and thus promote education which presumes new teachers as active and autonomous subjects, instead of "schooling" which presumes new teachers as objects of mentoring.

Korhonen et al. ${ }^{31}$ examined student teachers' experiences of participating in mixed peer mentoring groups of in-service and pre-service teachers. In their phenomenographical study they found that students' experiences were overall positive, but varied in terms of depth and the kind of learning it promoted. Four different categories were identified describing students considering PGM either as 1) a coffee break, 2) a forum of peer support, 3) place for identity construction or 4) a professional community. These categories varied in relation to meanings given to PGM meetings, topics of discussion, relationship between theory and practice, relationship between participants and what was learnt. For further development of the mixed groups model of in-service and pre-service teachers the researchers recommend paying more attention to fostering collegial relationships between participants and deeper integrating theoretical understanding with practical know-how.

It seems that the potential of PGM as a forum for sharing challenging and emotionally charged experiences varies between in-service and pre-service teachers' peer groups. While the study by Kaunisto et al. ${ }^{29}$ showed that a facilitated peer-group was an important forum for in-service teachers to share their emotionally coloured experiences, another study by Lassila et al. ${ }^{58}$ showed that student teachers might find it difficult to reveal their vulnerability and deeper emotions, and to respond constructively to peers' emotional outpouring in a group. Emotionally charged stories were often responded to with laughter and humor or by masking or silencing in student teachers' mentoring group. The researchers suggest that there may be a limit in the amount of vulnerability student teachers are willing to express, and that laughter, masking and silencing were used to hide emotional responses which might be seen as inappropriate for a 'proper' teacher. On the basis of their findings, the authors claim that teacher education should help students constructively reflect and cope with their emotions, and that PGM activities should be paired with other forms of reflection, such as storytelling, reading and writing. Uitto et al. ${ }^{60}$ have found out that through storytelling, teachers can raise issues that might otherwise be difficult to discuss. They conclude that narrative ways of working offer teachers an opportunity to recognize different dimensions of their identity and in this way trigger change.

The experienced benefits of PGM seem to vary to some extent depending on the stage of career of teachers. While newly qualified teachers tend to emphasize the increased selfconfidence, more experienced teachers value the creation of networks and broaden their perspectives. Teachers close to retirement age find PGM supporting their motivation. Common to all stages seems to be empowerment, strengthening identity and reduction of stress. $^{48}$

\section{Mentors' experiences}

While many studies have shown the benefits of PGM activities for mentees in terms of professional and identity development there is less research on mentors' experiences. Aspfors and Fransson ${ }^{61}$ see mentor training as necessary to promote prospective mentors' 
competence and understanding about the role of the mentor. In particular, they highlight the understanding of mentors' mission, the importance of concepts and perspectives, and analytical ability as well as the development of relational skills and communication skills. They also stress that to be successful, mentor training needs the integration of theory and practice. ${ }^{62}$ Jokinen, Markkanen, Teerikorpi and Heikkinen ${ }^{63}$ have reported on mentors' feedback concerning mentor training and new mentors' experiences of PGM. According to this report, mentor training was successful in integrating theory and practice, and the mentors found training as necessary for acting as a mentor in PGM. It has also been suggested that PGM training, emphasizing peerness, can be applied for leaders' training especially when new orientation to leadership is needed in organizational change and when professionals need to collaborate in teams and networks for developing their work. ${ }^{64}$

Studies on mentors' experiences of PGM have shown that mentors' conceptions of mentoring vary. ${ }^{65}$ For some, mentoring is about discussing and solving everyday problems, whereas some others emphasize collaborative reflection on more general issues related to work and professional identity. Shared understanding seems to prevail about mentors' main task, that is, supporting teachers' well-being at work. Acting as a mentor is also seen as a learning process ${ }^{25}$. Knowledge is shared and built together, rather than transformed from mentor to mentee. In addition to widened perspectives, mentors also have reported about feelings of collegial respect, sense of professional ethics, and personal positive disposition towards professional growth. ${ }^{66}$ In its best participation in PGM has empowered both mentees and mentors.

Kukkonen, Ranne and Korko ${ }^{25}$ emphasize dialogue as a central principle of mentoring encounter, and illustrate mentoring as an expedition with no defined destination. The interaction between the mentor and the other participants of the group is described as identity negotiation. In mentoring discussions 'the problems' are externalized, that is, separated from people, rather than internalized. In this way it is possible to avoid thoughts such as 'I am a bad teacher' or 'I am not able to join the work community'. As externalized the problems keep being separate from the identity of teacher, and the discussion about the problem is easier. In this kind of discussion the role of the mentor is not limited to being as a listener, questioner or supporter. The mentor is also a learner who builds his or her own teacher identity through externalized discussions with the group members. When encouraging and supporting the mentees the mentors start to see themselves and the problems of their own work communities in new light. In this way learning of the mentor may have indirect effects for the workplace development in the mentors work community.

Based on Erikson's ${ }^{67}$ theory of psychosocial development Laes, Tenhunen and Hanhela ${ }^{68}$ examined mentoring in terms of generativity. In Erikson's theory psychosocial development proceeds through eight stages, and in case of successful development an individual in middle adulthood achieves the state of generativity. Peculiar to this stage is that an individual strives to take care of other people, support younger generations and contribute to society. The authors found the concept of generativity describing well not only the teaching profession but also the role of mentor in peer groups. In PGM generativity manifests itself as concrete caring, attention and little gestures that get the members of the group feel welcomed, respected and appreciated. 
Peer-group mentoring involves intergenerational learning ${ }^{69-70}$ in which younger and older generations meet each other in dialogical conversations. Geeraerts et al. ${ }^{70}$ examined what and how teachers learn from their older and younger colleagues. In this study the participants were 11 Finnish teachers who acted as mentors in PGM groups, and 16 Belgian teachers who participated in a study of intergenerational knowledge brokerage among teachers. The participants reported that from their younger colleagues they had learnt innovative teaching methods and ICT skills, whereas from their more experienced colleagues they had learnt classroom management, practical information, self-regulation and community building. Both from younger and older teachers the participants reported learning of attitudes and different ways of being a teacher. In other words, teacher identity seems to be constructed in interaction between colleagues in different phases in their career. As the most important sources of learning teachers reported to be informal activities and relationships, mentoring in its different forms, seminars and working in teams.

\section{PGM in Administrative Structures of Education}

Our third research question pertained to the role of PGM in wider context of administrative structures of education. Here, two thematic research lines could be recognized: studies pertaining to the potential of PGM in workplace development in schools and colleges, and international comparative studies on national policies and models of mentoring.

\section{PGM as method for workplace development}

Some studies have explored the potential of PGM not only as a method of teachers' individual professional development, but also as a strategic approach to develop the school community as a whole. In a study by Geeraerts et al. ${ }^{39}$ it was found that majority of participants of PGM felt that it had generated ideas for developing a work community. The finding suggests that in addition to personal professional development, the influences of PGM may be reflected to the whole school community. This finding was significantly stronger in vocational schools.

Financial and functional support from the municipality as well as the principals' role have proven to be important in order to integrate mentoring into municipality's long-term continuing education strategy. ${ }^{71}$ One example is the city of Kokkola where peer-group mentoring has been embedded in the human resource development (HRD) strategy of educational staff. ${ }^{72}$ To contrast the individualistic working culture, PGM has been intentionally enacted as a form of professional learning community, which presupposes awareness of four conditions: understanding of (1) how the school functions, (2) what the prerequisites and conditions for developing school activities are, (3) how the developed operations and cultural characteristics are, and (4) how the tools and operations that are used to change school appear to the teacher. Johnson and Alamaa ${ }^{72}$ argue that in Kokkola, peer-group mentoring has met these conditions and because of that, teachers have experienced the collegial sharing, trust and encouragement in everyday work. In some other cases, it has turned out that lack of support from the municipality due to financial reasons has caused challenges. ${ }^{15}$. 
Hiltula et al. ${ }^{48}$ describe also the indirect influences of mentoring to school community based on the individuals' development. Participants in peer-group mentoring have reported the experiences of empowerment and creating networks with colleagues from different schools. Empowerment may encourage teachers to be more interactive in their school community and, for example, encourage them to introduce new ideas. Networking in the individual level can promote the collaboration between schools. Similar findings about indirect influences of PGM has suggested a study by Kukkonen et al. ${ }^{25}$

The findings about the indirect influences of PGM into the wider school community development are supported by a holistic model of professional growth by Nissilä and Paaso. ${ }^{73}$ The main idea is that professional growth starts from the individual's personal development and gradually moves towards collegial and organizational development. Essential parts of the model are versatile interaction, ethical reflections, awareness of various experiences, and theoretical scrutiny, and these can be manifested in peer-group mentoring.

\section{International comparisons}

International comparisons between different mentoring models may reveal the distinguishing features of the model, and some of such studies were available regarding the Finnish model of peer-group mentoring. In the comparison of the induction phase mentoring models of Estonia, Finland, and Sweden, Jokinen, Morberg, Poom-Valickis and Rohtma ${ }^{74}$ noted that PGM was characterized by the decentralized educational system, in which local municipalities have the main responsibility to organize support for teachers. Mentoring was described as the main strategy for teacher induction in most countries referred and examples had similarities and differences in terms of the implementation of mentoring, mentor education and organizational support for mentoring. The key finding was that mentoring needs to be addressed, organized and developed in terms of the local conditions in order to be vital and meaningful.

In his analysis of the differences of Finnish and Swedish educational cultures and their impact on mentoring approaches Fransson ${ }^{75}$ concluded that the Finnish model of PGM was developed through persevering pilot projects based on local circumstances and conditions (bottom-up approach), whereas in Sweden political decision makers have tended to directly adopt international models of mentoring which are being applied in a centrally directed way (top-down approach). One example was the aim to involve mentors participating in formal assessment of new teachers. In contrast, in Finland mentoring has been seen as a forum for learning without assessment. The emphasis on the autonomy of teaching profession has also been identified as a typical feature in the Finnish mentoring model..$^{8-9,13,37,38,76,77,78}$

Kemmis, Heikkinen, Fransson, Aspfors and Edwards-Groves ${ }^{13}$ provided examination of the practices of new teachers' mentoring in Australia, Finland and Sweden. They identified three archetypes of mentoring, which demonstrate the differing projects constituted by the particular arrangements, referred as practice architectures, in these empirical cases:

- Supervision: assisting new teachers to pass through probation. (Swedish case)

- Support: traditional mentoring where a more experienced teacher assists a mentee. (Australian case) 
- Collaborative self-development: professional growth through collegial mentoring. (Finnish case, PGM).

The important notion of the PGM was that collaborative self-development refers to both individual and collective professional growth, which is supported by the practice architectures in the Finnish education system. As an example of the Finnish policymaking, politicians and policy-makers have not expressed interests to increase the surveillance of teachers, or reduce the autonomy of teaching profession. Thus, the claim can be justified, that society does rely on teachers' professional ethics to develop their skills and competences, the school communities and teaching profession in Finland, and so the Finnish landscape for PGM can be described as high-trust environment and defined by the autonomous professionalism. ${ }^{38}$ This applies also to newly graduated teachers, since there is not an accreditation process and new teachers are assumed to have the necessary requirements for working life based on the extensive initial teacher education. ${ }^{77}$

\section{Discussion}

This review has shown that research on the Finnish model of peer-group mentoring has covered a range of topics from individuals' experiences to organizational and administrative perspectives. The issues emerging from studies can be grouped into the following themes, modified and elaborated from Aspfors et al. ${ }^{78}$ :

1. PGM in the continuum of teacher development

- challenges of transition from teacher education to teaching profession

- PGM as a tool to support newly qualified teachers

- PGM as a tool to support teachers throughout career

2. $\mathrm{PGM}$ in practice

- factors contributing to successful PGM

- different mentoring and PGM models

- experiences of mentees and mentees

- group formation and group dynamics

- role and dispositions of the mentor and mentees

3. Feasibility of PGM in terms of professional well-being

- potential to develop well-being at work

- influences into working community

4. $P G M$ and the administrative structures of education

-roles of the national administration, municipality and school principals

Table 1 summarizes the main results of PGM studies. The table is elaborated from our previous review on PGM in the early phase of the development of the model ${ }^{78}$. In he original version, the table presented two main themes of research: prerequisites of functional mentoring, and outcomes of PGM. As more recent studies have revealed also challenges in organizing PGM, we added this theme into the revised table. Furthermore, while the original table summarized the findings of early studies on the individual and organizational level, national level is added into the new version. Thus, the findings presented in Table 1 pertain to the following main themes: 1) prerequisites of functional mentoring activities, 2) outcomes, benefits and implications of PGM, and 3) challenges of 
the model. As regards the tiers of analysis, the findings can be classified into the three categories: findings related to individual and groups, findings pertaining to community and organization, and findings concerning national issues.

\section{INSERT TABLE 1 ABOUT HERE}

In addition to the significance of individual and group level social and methodological factors, the studies concerning prerequisites of functional mentoring have revealed the importance of administrative and organizational support for implementing PGM. The model has been developed as a bottom-up endeavor, and this may be the reason why it seems hard to achieve a sustainable position for it as a form of teacher development. Without legislation or national collective agreement about the principles and conditions of the activities PGM does not have an officially recognized status in the education system. This has made it possible for municipalities to cut spending on PGM in economically challenging times, which is reflected in low proportion of teachers participating in mentoring. Thus, conceptual change in terms of what is regarded as professional development is needed.

As to the individual and group level findings, the studies on mentors' and mentees' experiences of PGM have been highly positive from teachers' wellbeing as well as professional and identity development perspective. The challenges relate to managing group dynamics, time management and commitment.

Altogether, research on the Finnish model of peer-group mentoring has provided a rich knowledge base on the implementation of the model and on the experiences of participants and stakeholders. However, most of the studies have been conducted during or soon after the PGM period (usually one year long), whereas studies on long term effects are still called for. For example, it would be important to examine more the reported indirect influences of PGM on school development on the organizational level. An interesting question would be whether PGM practices contribute to change from individualistic working culture towards more collegial and networked culture. ${ }^{79}$

Methodologically, research on PGM has been dominantly qualitative, which can be explained by the fact that both the concept of PGM and the practices associated with it are still young. Therefore, it is important to develop understanding of the characteristics of the model. In the future, more quantitative studies are welcome to examine the extent of experiences and characteristics of the model. Furthermore, studies from the ecosystems or ecologies of practices perspective ${ }^{80}$ are needed in order to understand the nature of the development of the PGM model in relation to wider educational policy context.

Based on the review of research, the Finnish model of PGM has been a successful innovation in the field of professional development. However, we stress that due to different sociocultural contexts, mentoring models cannot be borrowed from one national context to another as such. The Finnish model is based on shared values of the Finnish society and education system, and the model as such may not function in a similar way in different 
societies. It is concluded that PGM as well as teachers' professional development as a whole should be seen as an integral part of the education ecosystem.

\section{Acknowledgements}

The authors wish to thank all the members of the Finnish Network for Peer-Group Mentoring for the most fruitful collaboration. We also thank the Finnish Work Environment Fund, Nordplus Horizontal and the Nordic Council of Ministers, and the Finnish Ministry of Education and Culture for funding the research and development of the PGM model.

The article was written in collaboration by the research group coordinating the Finnish Network for Peer-group Mentoring, and the external researcher, Päivi Tynjälä. The material consisting of 46 publications was shared among the four authors, and each of them read and analyzed their own share, and recorded data into the excel sheet. The external researcher, Päivi Tynjälä wrote the most part of the manuscript, and the other three authors completed the text by writing sections that were agreed on. The names are listed according to the amount of the authors' contribution. The authors together are responsible for the integrity of the data analyzed.

\section{Competing interests}

Hannu Heikkinen, Ilona Markkanen, and Matti Pennanen are the coordinators of the Finnish Network for Peer-group Mentoring, which has been developing the PGM model and training of mentors. Päivi Tynjälä used to be a member of the coordination group till 2016.

\section{References}

1. Roberts, A. 2000. Mentoring Revisited: a phenomenological reading of the literature. Mentoring \& Tutoring: Partnership in Learning 8: 145-170.

2. Orland-Barak, L. (2010). Learning to Mentor-as-Praxis: Foundations for a Curriculum in Teacher Education (Vol. 4). Springer Science \& Business Media.

3. Bozeman, B., and Feeney, M. K. 2007. Toward a useful theory of mentoring: A conceptual analysis and critique. Administration \& Society, 39: 719-739.

4. Bozeman, B., Darwin, A., and E. Palmer. 2009. Mentoring circles in higher education. Higher Ed. Res. \& Dev.28: 125-136.

5. Huizing, R. 2012. Mentoring together: a literature review of group mentoring. Mentoring and Tutoring: Partnership in Learning 20: 27-55.

6. Heikkinen, H., Jokinen, H., \& Tynjälä, P. 2012. Teacher education and development as lifelong and lifewide learning. In Peer-group Mentoring for Teacher Development, $\mathrm{H}$. Heikkinen, H. Jokinen, \& P. Tynjälä Eds.: 3-30. London: Routledge.

7. European Commission. 2010. Developing Coherent and System-wide Induction Programmes for Beginning Teachers: A Handbook for Policymakers. European Commission Staff Working Document SEC (2010) 538 Final. Brussels: Commission of the European Communities. 
8. Välijärvi, J., \& Heikkinen, H. 2012. Peer-group mentoring and the culture of education in Finland. In Peer-group Mentoring for Teacher Development. $\mathrm{H}$. Heikkinen, H. Jokinen, \& P. Tynjälä, Eds.: 31-40. London: Routledge

9. Sahlberg, P. 2011. Finnish Lessons. New York, NY: Teachers College Press.

10. Ministry of Education and Culture. 2016. Teacher Education Development Program. Assessed August 5, 2019.

https://minedu.fi/documents/1410845/4183002/Teacher+Education+Development+ Programme+2016

11. Finnish Network of PGM. 2019. Website, August 30, 2019. http://osaavaverme.wixsite.com/verme/en

12. Koivisto, Yli-Suomu \& Pakarinen, 2012. Mentorointi ja osaamisen kehittäminen. In Osaaminen jakoon: Vertaisryhmämentorointi opetusalalla. H. Heikkinen, H. Jokinen, I. Markkanen, \& P. Tynjälä, Eds.: 255-267. Jyväskylä: PS-Kustannus.

13. Kemmis, S., Heikkinen, H., Fransson, G., Aspfors, J., et al. 2014. Mentoring of new teachers as a contested practice: Supervision, support and collaborative selfdevelopment. Teaching and Teacher Ed., 43: 154-164.

14. Heikkinen, H., Jokinen, H., Markkanen, I., \& Tynjälä, P. Eds. 2012. Osaaminen jakoon: Vertaisryhmämentorointi opetusalalla. Jyväskylä: PS-Kustannus.

15. Pennanen, M., Heikkinen \& Markkanen, I. Eds. 2019. Verme ${ }^{2}$ testaa: Kokemuksia vertaisryhmämentoroinnin soveltamisesta. Jyväskylä: Jyväskylän yliopisto: Koulutuksen tutkimuslaitos. http://urn.fi/URN:ISBN:978-951-39-7799-3

16. OECD. 2018. TALIS 2018 Results (Volume I). Teachers and School Leaders as Lifelong Learners. Paris: OECD. Assessed Nov 10, 2019. DOI:https://doi.org/10.1787/1d0bc92a-en

17. Hynynen, M.-A., Ojala, K., \& Abdelhamid, P. 2016. Vertaisryhmämentorointi yhdessä oppimista ja osaamisen jakamista. Sosiaaliääketieteellinen Aikakauslehti, 53(1). https://journal.fi/sla/article/view/55933. Assessed August 29, 2019.

18. Koulutusaineistot, 2019. Kyllä me taidamme! Vertaisoppimisen ideapäivä 11.3. Assessed August 28, 2019. https://uudenmaankirjastot.fi/aineistopankki/koulutusaineistot/.

19. Heikkinen, H., Jokinen, H. \& Tynjälä, P. 2008. Reconceptualising mentoring as a dialogue. In Newly Qualified Teachers in Northern Europe. G. Fransson \& C. Gustavsson, Eds.: 107-124. University of Gävle. Teacher Education, Research Publications 4.

20. Mäki, P. 2012. Diverse landscapes of mentoring. In Peer-group mentoring for teacher development, H. Heikkinen, H. Jokinen, \& P. Tynjälä, Eds.: 71-77. London: Routledge.

21. Ennser-Kananen, J., \& Ruohotie-Lyhty, M. 2019. I'm a foreign teacher": Legitimate positionings in the stories of a migrant teacher. [Submitted]

22. Kalberg-Granlund \& Korpinen, 2012. Vertaistuki pienessä koulussa. In Osaaminen jakoon: Vertaisryhmämentorointi opetusalalla. H. Heikkinen, H. Jokinen, I. Markkanen, \& P. Tynjälä, Eds.:159-169. Jyväskylä: PS-Kustannus.

23. Estola, E. Aho, J., Kaunisto, S-L. Moilanen, A. \& Tervonen, J. 2012. Kerronnalliset ja toiminnalliset menetelmät. In Osaaminen jakoon: Vertaisryhmämentorointi opetusalalla. H. Heikkinen, H. Jokinen, I. Markkanen, \& P. Tynjälä, Eds.:155-172. Jyväskylä: PS-Kustannus. 
24. Aarnio, H. \& Mäki-Hakola, H. 2012. Dialogikortit mentorin työkaluina. In Osaaminen jakoon: Vertaisryhmämentorointi opetusalalla. H. Heikkinen, H. Jokinen, I. Markkanen, \& P. Tynjälä, Eds.:125-148. Jyväskylä: PS-Kustannus.

25. Kukkonen, H. Ranne, K. \& Korko,K-M. 2012. Vastavuoroinen oppiminen vermessä. In Osaaminen jakoon: Vertaisryhmämentorointi opetusalalla. H. Heikkinen, H. Jokinen, I. Markkanen, \& P. Tynjälä, Eds.:149-158. Jyväskylä: PS-Kustannus.

26. Estola, E., Heikkinen, H., \& Syrjälä, L. 2014. Narrative pedagogies for peer groups. In International Teacher Education: Promising Pedagogies (Part A), C. J. Craig \& L. Orland-Barak, Eds.:155-172. Bingley: Emerald.

27. Ahokas, M. 2012. A multiprofessional mentoring group at a vocational school. In Peer-group Mentoring for Teacher Development, H. Heikkinen, H. Jokinen, \& P. Tynjälä, Eds.: 89-96. London: Routledge.

28. Lahdenmaa, M., \& Heikkinen, H. 2012. Experiences of peer-group mentoring in homogenous and heterogenous groups. In Peer-group Mentoring for Teacher Development, H. Heikkinen, H. Jokinen, \& P. Tynjälä, Eds.: 97-103. London: Routledge.

29. Kaunisto, S.-L., Uitto, M., Estola, E., \& Syrjälä, L. 2009. Ohjattu vertaisryhmä haavoittuvuudesta kertomisen paikkana. Kasvatus, 40, 454-464.

30. Kiviniemi, U., Heikkinen, H., Tynjälä, P., \& Martin, A. 2019. Running a hybrid: Mingling in-service and pre-service teachers in peer-mentoring groups. [Submitted]

31. Korhonen, H., Heikkinen, H., Kiviniemi, U., \& Tynjälä, P. 2017. Student teachers' experiences of participating in mixed peer mentoring groups of in-service and preservice teachers in Finland. Teaching and Teacher Ed., 61, 153-163.

32. Uitto, M., Kaunisto, S.-L., Kelchtermans, G., \& Estola, E. 2016. Peer group as a meeting place: reconstructions of teachers' self-understanding and the presence of vulnerability. Int.J. of Ed. Res, 75, 7-16.

33. Estola, E., Syrjälä, L., \& Maunu, T. 2012. The first years as a teacher. In Peer-group Mentoring for Teacher Development, H. Heikkinen, H. Jokinen, \& P. Tynjälä, Eds.: 4351. London: Routledge.

34. Heikkinen, H.L.T., Markkanen, I., \& Pennanen, M. 2019. Johtopäätöksiä ja suosituksia. In. Verme ${ }^{2}$ testaa. Kokemuksia vertaisryhmämentoroinnin soveltamisesta. M. Pennanen, I. Markkanen \& H.L.T. Heikkinen, Eds.:83-88. Jyväskylän yliopisto: Koulutuksen tutkimuslaitos.

35. Wittek, D., Ruohotie-Lyhty, M., \& Heikkinen, H. 2017. Mentoring im Berufseinstieg von Lehrpersonen - ein bilateraler Vergleich zwischen Deutschland und Finnland. Die Deutsche Schule, 22(1), 34-42.

36. Teerikorpi, S., \& Heikkinen, H. 2012. Keys to success. In Peer-group Mentoring for Teacher Development, H. Heikkinen, H. Jokinen, \& P. Tynjälä, Eds.: 121-128. London: Routledge.

37. Pennanen, M., Heikkinen, H. \& Tynjälä, P. 2018. Virtues of mentors and mentees in the Finnish model of teachers' peer-group mentoring. Scandinavian J. of Ed. Res. https://doi.org/10.1080/00313831.2018.1554601

38. Heikkinen, H., Wilkinson, J., Aspfors, J., \& Bristol, L. 2018. Understanding mentoring of new teachers: Communicative and strategic practices in Australia and Finland. Teaching and Teacher Ed., 71, 1-11.

39. Geeraerts, K., Tynjälä, P., Heikkinen, H., Markkanen, I., et al. 2015. Peer-group mentoring as a tool for teacher development. Eur. J. of Teacher Ed., 38, 358-377. 
40. Onnismaa, E. L., Tahkokallio, L., Lipponen, L., \& Merivirta, J. 2016.

Lastentarhanopettajien ryhmämuotoinen vertaismentorointi ammatin induktiovaiheen tukena. [Kindergarten teachers' group-based peer mentoring as support for the induction phase in the profession] Research report of a mentoring project. City of Helsinki, Early childhood services and University of Helsinki, Department of Education.

41. Alanko-Turunen, M. and Pasanen, H. 2012. Verme ammatillisen opettajan tukena muutosten kentällä. In Osaaminen jakoon: Vertaisryhmämentorointi opetusalalla. $\mathrm{H}$. Heikkinen, H. Jokinen, I. Markkanen, \& P. Tynjälä, Eds.:173-187. Jyväskylä: PSKustannus.

42. Nissilä, S.-P. 2013. The vocational teacher's changing role and identity in changing contexts. In Practical skills, education and development: Vocational Education and Training in Finland. K. Aaltonen, A, Isacsson, J. Laukia, \& L. Vanhanen-Nuutinen, Eds.:. 95-108. Helsinki: Haaga-Helia.

43. Nissilä, S.-P., Karjalainen, A., Koukkari, M., \& Kepanen, P. 2015. Towards competence-based practices in vocational education - what will the process require from teacher education and teacher identities? CEPS J., 5(2), 13-34.

44. Töytäri, A., Tynjälä, P., Piirainen, A. \& Ilves, V. 2017. Higher education teachers' descriptions of their own learning: a quantitative perspective. Higher Education Research \& Development 36, 1295-1304.

45. Kaunisto, S.-L., Estola, E., \& Niemistö, R. 2012. The group as a context for peer-group mentoring. In Peer-group Mentoring for Teacher Development. H. Heikkinen, H. Jokinen \& P. Tynjälä, Eds.:112-120. London: Routledge.

46. Tuckman, B. 1965. Developmental sequence in small groups. Psychological Bulletin 63, 384-399.

47. Kaunisto, S.-L., Estola, E., \& Leiman, M. 2013. "I've Let Myself Get Tired" - one teacher's self-reflection process in a peer group. Reflective Practice, 14, 406-419.

48. Hiltula, A., Isosomppi, L., Jokinen, H., \& Oksakari, A. 2012. Individual and social meanings of mentoring. In Peer-group Mentoring for Teacher Development, $\mathrm{H}$. Heikkinen, H. Jokinen, \& P. Tynjälä Eds.: 60-70. London: Routledge.

49. Tillander, K. 2018. Vermestä voimaa - vertaisryhmämentorointi tukemassa opettajan jaksamista ja ammatillista kehitystä. Teoksessa TAMK konferenssi - TAMK conference 2018. T. Kenttälä-Koivumäki, Ed.:134-142. Tampere: Tampereen ammattikorkeakoulu. Assessed August 5, 2019. https://www.tamk.fi/-/tamkkonferenssi-tamk-conference-2018

50. Tynjälä, P., \& Heikkinen, H. 2011. Beginning teachers' transition from pre-service education to working life: Theoretical perspectives and best practices. Zeitschrift für Erziehungswissenschaft, 14, 11-34.

51. Aspfors, J., \& Eklund, G. 2017. Explicit and implicit perspectives on research-based teacher education - newly qualified teachers' experiences in Finland. J. of Education for Teaching: International Research and Pedagogy, 43, 400-413.

52. Aspfors, J., Bendtsen, M., \& Hansén, S.-E. 2011. Nya lärare möter skola och klassrum. In Allmändidaktik en vetenskap för lärare. S.-E. Hansén \& L. Forsman, Eds.: 331-353. Lund: Studentlitteratur.

53. Aspfors, J., Bendtsen, M., Hansén, S.-E, \& Sjöholm, K. 2011. Evolving views of the teaching profession: Voices from student teachers and newly qualified teachers. In Becoming a teacher. Nordic perspectives on teacher education and newly qualified 
teachers. U. Lindgren, F. Hjardemaal, K. Sjöholm, \& S.-E. Hansén, Eds.: 23-46. Vasa: Åbo Akademi University.

54. Jokikokko, K., Uitto, M., Deketelaere, A., \& Estola, E. 2017. A beginning teacher in emotionally intensive micropolitical situations. Int. J. of Ed. Res. 81, 61-70.

55. Aspfors, J., \& Bondas, T. 2013. Caring about caring: Newly qualified teachers' experiences of their relationships within the school community. Teachers and Teaching: Theory and Practice, 19, 243-259.

56. Jokinen, H., Heikkinen, H., \& Morberg, Å. 2012. The induction phase as a critical transition for newly qualified teachers. In Transitions and transformations in learning and education. P. Tynjälä, M.-L. Stenström, \& M. Saarnivaara, Eds.: 169-186. Dordrecht: Springer.

57. Heikkinen, H., Aho, J., \& Korhonen, H. 2015. Ope ei saa oppia: Opettajankoulutuksen jatkumon kehittäminen. Jyväskylä: Jyväskylän yliopisto, Koulutuksen tutkimuslaitos

58. Lassila, E. T., Jokikokko, K., Uitto, M., \& Estola, E. 2017. The challenges to discussing emotionally loaded stories in Finnish teacher education. Eur. J. of Teacher Ed., 40, 379-393.

59. Heikkinen, H. L. (2017). Mentoring of newly qualified teachers in the educational sense. In A Companion to Research in Teacher Education. M. A. Peters, B. Cowie, \& I. Menter, Eds.: 813-824. Springer: Singapore.

60. Uitto, M., Kaunisto, S-L., Syrjälä, L. \& Estola, E. 2015. Silenced truths: relational and emotional dimensions of a beginning teacher's identity as part of the micropolitical context of school. Scand. J. of Ed. Research, 59: 162-176.

61. Aspfors, J., \& Fransson, G. 2015. Research on mentor education for mentors of newly qualified teachers: A qualitative meta-synthesis. Teaching and Teacher Ed., 48: 75-86.

62. Aspfors, J., \& Fransson, G. 2015. Att kvalificera sig till mentor - perspektiv på kompetensbehov och utbildning av mentorer för nya lärare. Psykologi i Kommunen, 50(2), 17-27.

63. Jokinen, H., Markkanen, I., Teerikorpi, S., \& Heikkinen, H. 2012. Mentorikoulutus. In Osaaminen jakoon: Vertaisryhmämentorointi opetusalalla. H. Heikkinen, H. Jokinen, I. Markkanen, \& P. Tynjälä, Eds.:87-95. Jyväskylä: PS-Kustannus.

64. Pasanen, H., \& Alanko-Turunen, M. 2019. Vertaisuuden tunnustaminen esimiesorientaationa Verme-koulutus jaettua johtajuutta kehittämässä. Aikuiskasvatus, 39(1). doi:https://doi.org/10.33336/aik.80254

65. Syrjälä, L. \& Estola, E 2012. Diversity of mentoring. Peer-group mentoring for teacher development. In H. Heikkinen, H. Jokinen, \& P. Tynjälä, Eds.: 104-111. London: Routledge

66. Nissilä, S.-P. 2015. Designing and testing an educational program for professional development in work places: Sharing expertise in teachers' peer group mentoring. In Education - research - evaluation, D. Hanesova, Ed.: 81-99. Banska Bystrica: Univerzita Mateja Bela.

67. Erikson, E.H. 1982. The Life Cycle Completed. New York: Norton.

68. Laes, Tenhunen \& Hanhela 2012. Vertaisryhmämentorointi generatiivisuuden näkökulmasta. In Osaaminen jakoon: Vertaisryhmämentorointi opetusalalla. H. Heikkinen, H. Jokinen, I. Markkanen, \& P. Tynjälä, Eds.:207-222. Jyväskylä: PSKustannus. 
69. Ropes, D. 2013. Intergenerational learning in organizations. Eur. J. of Training and Development, 37: 713-727.

70. Geeraerts, K., Tynjälä, P., \& Heikkinen, H. 2018. Inter-generational learning of teachers: what and how do teachers learn from older and younger colleagues? Eur. J. of Teacher Ed., 41: 479-495.

71. Rajakaltio, H., \& Syrjäläinen, E. 2012. Peer-group mentoring in the context of transforming local administration. In Peer-group Mentoring for Teacher Development, H. Heikkinen, H. Jokinen, \& P. Tynjälä, Eds.: 78-88. London: Routledge

72. Johnson, P., \& Alamaa, S. 2012. Mentoring as sustainable school development. In Peer-group Mentoring for Teacher Development. H. Heikkinen, H. Jokinen, \& P. Tynjälä, Eds.: 52-59. London: Routledge.

73. Nissilä \& Paaso 2012. Itsetuntemuksesta organisaation kehittämiseen. In Osaaminen jakoon: Vertaisryhmämentorointi opetusalalla. H. Heikkinen, H. Jokinen, I. Markkanen, \& P. Tynjälä, Eds.: 189-206. Jyväskylä: PS-Kustannus.

74. Jokinen, H., Morberg, Å., Poom-Valickis, K. \& Rohtma, V. 2008. Mentoring newly qualified teachers in Estonia. Finland and Sweden. In Newly qualified teachers in Northern Europe. Comparative perspectives on promoting professional development. G. Fransson \& C. Gustavsson, Eds.: 76-106. Gävle: University of Gävle.

75. Fransson, G. 2014. A culture of trust or an ideology of distrust: A comparison of the impact of Finnish and Swedish educational cultures on mentoring approaches. Uncovering the Hidden Cultural Dynamics in Mentoring: Uncovering the Complexitiess. In F. Kochan, A. Kent, and A. Green, Eds.: 253-271. Charlotten NC: Information Age Press.

76. Aspfors, J., Fransson, G., \& Heikkinen, H. 2012. Mentoring as dialogue, collaboration and/or assessment? In Transitions and transformations in learning and education. $P$. Tynjälä, M.-L. Stenström, \& M. Saarnivaara, Eds.: 271-290. Dordrecht: Springer.

77. Pennanen, M., Bristol, L., Wilkinson, J., \& Heikkinen, H. 2016. What is 'good'mentoring? Understanding mentoring practices of teacher induction through case studies of Finland and Australia. Pedagogy, Culture \& Society, 24, 27-53

78. Aspfors, J., Hansén, S.-E., Tynjälä, P., Heikkinen, H., et al. 2012. Lessons learnt from peer-group mentoring experiments. In Peer-group Mentoring for Teacher Development, H. Heikkinen, H. Jokinen, \& P. Tynjälä Eds.: 131-143. London: Routledge.

79. Hargreaves, A., \& Fullan, M. 2012. Professional Capital: Transforming Teaching in Every School. Teachers College Press.

80. Kemmis, S., \& Heikkinen, H. 2012. Future perspectives: Peer-group mentoring and international practices for teacher development. In Peer-group Mentoring for Teacher Development, H. Heikkinen, H. Jokinen, \& P. Tynjälä, Eds.: 144-170. London: Routledge. 
Table 1. Summary of the findings of PGM studies (adapted from Ref. 78, p. 140)

\begin{tabular}{|c|c|c|c|}
\hline Main themes & Individual/Group level & $\begin{array}{l}\text { Community/ } \\
\text { Organizational level }\end{array}$ & National level \\
\hline $\begin{array}{l}\text { Prerequisites of } \\
\text { functional } \\
\text { mentoring } \\
\text { activities }\end{array}$ & $\begin{array}{l}\text { Social factors: } \\
\text { open } \\
\text { atmosphere, } \\
\text { mutual trust } \\
\text { Methodological } \\
\text { factors: rules, } \\
\text { agreements }\end{array}$ & $\begin{array}{l}\text { Administrative } \\
\text { factors: } \\
\text { organizational } \\
\text { support } \\
\text { - Physical factors: } \\
\text { time and place } \\
\text { convenient } \\
\end{array}$ & $\begin{array}{l}\text { - } \begin{array}{l}\text { Funding } \\
\text { and }\end{array} \\
\text { agreement } \\
\mathrm{s}\end{array}$ \\
\hline $\begin{array}{l}\text { Outcomes/benefit } \\
\text { s/ implications of } \\
\text { PGM }\end{array}$ & 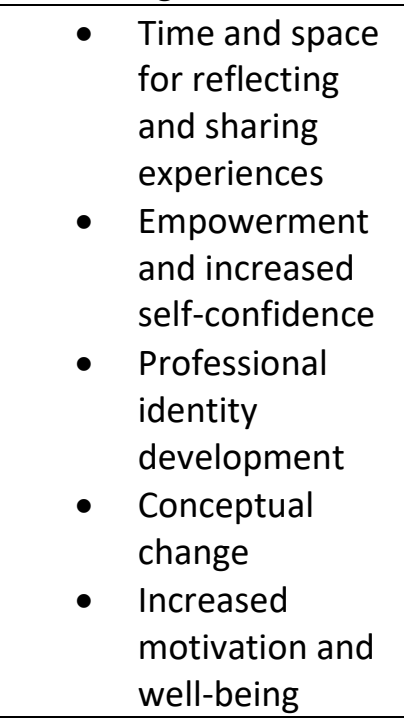 & $\begin{array}{l}\text { Mainly indirect } \\
\text { effects: } \\
\text { empowered } \\
\text { teachers act as } \\
\text { agents of change } \\
\text { - More direct effects } \\
\text { when teachers } \\
\text { come from the } \\
\text { same school and } \\
\text { when the groups } \\
\text { are } \\
\text { multidisciplinary. } \\
\text { One possible } \\
\text { method for teacher } \\
\text { induction }\end{array}$ & $\begin{array}{l}\text { National } \\
\text { network } \\
\text { for } \\
\text { mentoring } \\
\text { and } \\
\text { teacher } \\
\text { induction } \\
\text { - Research- } \\
\text { based } \\
\text { practice }\end{array}$ \\
\hline Challenges & $\begin{array}{l}\text { - Group dynamics } \\
\text { (e.g. } \\
\text { dominant/withd } \\
\text { rawing persons } \\
\text { in group) } \\
\text { - Time } \\
\text { management } \\
\text { and } \\
\text { commitment }\end{array}$ & $\begin{array}{l}\text { Recognition of } \\
\text { peer learning as } \\
\text { professional } \\
\text { development }\end{array}$ & $\begin{array}{ll}\text { - } & \text { Lack of } \\
\text { national } \\
\text { agreement } \\
\text { - } \quad \text { Compensa } \\
\text { tion for } \\
\text { mentors } \\
\text { - } \quad \text { Allocation } \\
\text { of working } \\
\text { time for } \\
\text { mentees }\end{array}$ \\
\hline
\end{tabular}




\begin{tabular}{|c|c|c|c|c|c|}
\hline Authors & Year & Title & $\begin{array}{l}\text { Number of } \\
\text { participants }\end{array}$ & Data & Methods \\
\hline Ahokas, M. & 2012 & $\begin{array}{l}\text { A multiprofessional } \\
\text { mentoring group at a } \\
\text { vocational school. }\end{array}$ & $\begin{array}{l}26 \\
\text { participants, } 2 \\
\text { mentors and } \\
24 \text { mentees. }\end{array}$ & $\begin{array}{l}\text { Thematic } \\
\text { interviews, }\end{array}$ & Case study \\
\hline $\begin{array}{l}\text { Alanko- } \\
\text { Turunen, } \mathrm{M} \text {. } \\
\text { \& Pasanen, } \mathrm{H} \text {. }\end{array}$ & 2012 & $\begin{array}{l}\text { Verme ammatillisen } \\
\text { opettajan tukena } \\
\text { muutosten kentällä }\end{array}$ & $\begin{array}{l}22 \text { mentors in } \\
\text { vocational } \\
\text { education }\end{array}$ & $\begin{array}{l}\text { Participants' } \\
\text { learning and } \\
\text { research tasks }\end{array}$ & Thematic analysis \\
\hline $\begin{array}{l}\text { Aspfors, J., \& } \\
\text { Bondas, T. }\end{array}$ & 2013 & $\begin{array}{l}\text { Caring about caring: } \\
\text { Newly qualified } \\
\text { teachers' experiences of } \\
\text { their relationships } \\
\text { within the school } \\
\text { community. }\end{array}$ & $\begin{array}{l}88 \text { newly } \\
\text { qualified } \\
\text { teachers }\end{array}$ & $\begin{array}{l}\text { Online } \\
\text { questionnaire, } \\
\text { open ended } \\
\text { questions, } 88 \\
\text { respondents }\end{array}$ & $\begin{array}{l}\text { Qualitative content } \\
\text { analysis, inductive } \\
\text { and explorative }\end{array}$ \\
\hline $\begin{array}{l}\text { Aspfors, J., \& } \\
\text { Eklund, G. }\end{array}$ & 2017 & $\begin{array}{l}\text { Explicit and implicit } \\
\text { perspectives on } \\
\text { research-based teacher } \\
\text { education - newly } \\
\text { qualified teachers' } \\
\text { experiences in Finland }\end{array}$ & $\begin{array}{l}10 \text { newly } \\
\text { qualified } \\
\text { primary school } \\
\text { teachers }\end{array}$ & $\begin{array}{l}\text { Semi-structured } \\
\text { interviews with }\end{array}$ & $\begin{array}{l}\text { Qualitative content } \\
\text { analysis }\end{array}$ \\
\hline $\begin{array}{l}\text { Aspfors, J., \& } \\
\text { Fransson, G. }\end{array}$ & 2015 & $\begin{array}{l}\text { Att kvalificera sig till } \\
\text { mentor - perspektiv på } \\
\text { kompetensbehov och } \\
\text { utbildning av mentorer } \\
\text { för nya lärare }\end{array}$ & NA & Literature & Review \\
\hline $\begin{array}{l}\text { Aspfors, J., \& } \\
\text { Fransson, G. }\end{array}$ & 2015 & $\begin{array}{l}\text { Research on mentor } \\
\text { education for mentors } \\
\text { of newly qualified } \\
\text { teachers: A qualitative } \\
\text { meta-synthesis. }\end{array}$ & NA & 10 studies & $\begin{array}{l}\text { Qualitative meta- } \\
\text { synthesis }\end{array}$ \\
\hline $\begin{array}{l}\text { Aspfors, J., } \\
\text { Bendtsen, M., } \\
\text { \& Hansén, S.- } \\
\text { E. }\end{array}$ & 2011 & $\begin{array}{l}\text { Nya lärare möter skola } \\
\text { och klassrum. }\end{array}$ & 2 teachers & $\begin{array}{l}\text { Questionnaire / } \\
\text { focus group }\end{array}$ & Narrative analysis \\
\hline $\begin{array}{l}\text { Aspfors, J., } \\
\text { Bendtsen, M., } \\
\text { Hansén, S.-E, } \\
\text { \& Sjöholm, K. }\end{array}$ & 2011 & $\begin{array}{l}\text { Evolving views of the } \\
\text { teaching profession: } \\
\text { Voices from student } \\
\text { teachers and newly } \\
\text { qualified teachers. }\end{array}$ & 76 teachers & $\begin{array}{l}\text { Questionnaire } \\
\text { and focus group } \\
\text { interviews }\end{array}$ & $\begin{array}{l}\text { Qualitative content } \\
\text { analysis }\end{array}$ \\
\hline $\begin{array}{l}\text { Aspfors, J., } \\
\text { Fransson, G., }\end{array}$ & 2012 & $\begin{array}{l}\text { Mentoring as dialogue, } \\
\text { collaboration and/or } \\
\text { assessment? }\end{array}$ & $\begin{array}{l}118 \\
\text { (questionnaire) }\end{array}$ & $\begin{array}{l}\text { Interviews; } \\
\text { questionnaire, }\end{array}$ & Content analysis \\
\hline
\end{tabular}




\begin{tabular}{|c|c|c|c|c|c|}
\hline $\begin{array}{l}\text { \& Heikkinen, } \\
\text { H. }\end{array}$ & & & $\begin{array}{l}+5 \\
\text { (interviews) }\end{array}$ & $\begin{array}{l}\text { national policy } \\
\text { documents }\end{array}$ & \\
\hline $\begin{array}{l}\text { Aspfors, J., } \\
\text { Hansén, S.-E., } \\
\text { Tynjälä, P., } \\
\text { Heikkinen, H., } \\
\text { \& Jokinen, H. }\end{array}$ & 2012 & $\begin{array}{l}\text { Lessons learnt from } \\
\text { peer-group mentoring } \\
\text { experiments. }\end{array}$ & NA & Literature & Review \\
\hline $\begin{array}{l}\text { Estola, E., } \\
\text { Heikkinen, H., } \\
\text { \& Syrjälä, L. }\end{array}$ & 2014 & $\begin{array}{l}\text { Narrative pedagogies for } \\
\text { peer groups. }\end{array}$ & NA & Literature & $\begin{array}{l}\text { Theoretical review } \\
\text { of narrative } \\
\text { identity work }\end{array}$ \\
\hline $\begin{array}{l}\text { Estola, E., } \\
\text { Syrjälä, L., \& } \\
\text { Maunu, T. }\end{array}$ & 2012 & $\begin{array}{l}\text { The first years as a } \\
\text { teacher. }\end{array}$ & 7 participants & $\begin{array}{l}\text { Participatory } \\
\text { observation, } \\
\text { notes, writing } \\
\text { assignments, } \\
\text { essays }\end{array}$ & $\begin{array}{l}\text { Inductive, } \\
\text { thematical analysis }\end{array}$ \\
\hline Fransson, G. & 2014 & $\begin{array}{l}\text { A culture of trust or an } \\
\text { ideology of distrust: A } \\
\text { comparison of the } \\
\text { impact of Finnish and } \\
\text { Swedish educational } \\
\text { cultures }\end{array}$ & NA & $\begin{array}{l}\text { Literature, policy } \\
\text { documents }\end{array}$ & $\begin{array}{l}\text { Review and macro- } \\
\text { level comparative } \\
\text { analysis }\end{array}$ \\
\hline $\begin{array}{l}\text { Geeraerts, K., } \\
\text { Tynjälä, P., \& } \\
\text { Heikkinen, H. }\end{array}$ & 2018 & $\begin{array}{l}\text { Inter-generational } \\
\text { learning of teachers: } \\
\text { what and how do } \\
\text { teachers learn from } \\
\text { older and younger } \\
\text { colleagues? }\end{array}$ & $\begin{array}{l}16 \text { Belgian } \\
\text { teachers, } 11 \\
\text { Finnish } \\
\text { teachers, } \\
\text { altogether } \\
n=27\end{array}$ & $\begin{array}{l}\text { FI: written } \\
\text { accounts, BE: } \\
\text { interviews }\end{array}$ & Thematic analysis \\
\hline $\begin{array}{l}\text { Geeraerts, K., } \\
\text { Tynjälä, P., } \\
\text { Heikkinen, H., } \\
\text { Markkanen, } \\
\text { I., Pennanen, } \\
\text { M., \& Gijbels, } \\
\text { D. }\end{array}$ & 2015 & $\begin{array}{l}\text { Peer-group mentoring as } \\
\text { a tool for teacher } \\
\text { development. }\end{array}$ & $\begin{array}{l}69 \text { general } \\
\text { education, } 47 \\
\text { vocational edu } \\
\text { teachers, } \\
\text { altogether } \\
n=116\end{array}$ & $\begin{array}{l}\text { Quantitative } \\
\text { online survey }\end{array}$ & $\begin{array}{l}\text { Quantitative } \\
\text { methods: CFA + } \\
\text { EFA, descriptive } \\
\text { statistics, group } \\
\text { comparison with t- } \\
\text { test }\end{array}$ \\
\hline Heikkinen, $\mathrm{H}$. & 2016 & $\begin{array}{l}\text { Bridging informal and } \\
\text { formal learning in } \\
\text { professional } \\
\text { development. }\end{array}$ & NA & $\begin{array}{l}\text { Philosophical } \\
\text { literature }\end{array}$ & Review \\
\hline Heikkinen, $\mathrm{H}$. & 2017 & $\begin{array}{l}\text { Mentoring of newly } \\
\text { qualified teachers in the } \\
\text { educational sense. }\end{array}$ & NA & Literature & $\begin{array}{l}\text { Philosophical } \\
\text { review }\end{array}$ \\
\hline $\begin{array}{l}\text { Heikkinen, H., } \\
\text { Jokinen, H., \& } \\
\text { Tynjälä, P. }\end{array}$ & 2012 & $\begin{array}{l}\text { Teacher education and } \\
\text { development as lifelong } \\
\text { and lifewide learning. }\end{array}$ & NA & Literature & Review \\
\hline
\end{tabular}




\begin{tabular}{|c|c|c|c|c|c|}
\hline $\begin{array}{l}\text { Heikkinen, H., } \\
\text { Wilkinson, J., } \\
\text { Aspfors, J., \& } \\
\text { Bristol, L. }\end{array}$ & 2018 & $\begin{array}{l}\text { Understanding } \\
\text { mentoring of new } \\
\text { teachers: } \\
\text { Communicative and } \\
\text { strategic practices in } \\
\text { Australia and Finland. }\end{array}$ & 8 teachers & $\begin{array}{l}\text { Audio recorded } \\
\text { interviews in } \\
\text { Australia and in } \\
\text { Finland }\end{array}$ & $\begin{array}{l}\text { Abductive content } \\
\text { analysis }\end{array}$ \\
\hline $\begin{array}{l}\text { Hiltula, A., } \\
\text { Isosomppi, L., } \\
\text { Jokinen, H., \& } \\
\text { Oksakari, A. }\end{array}$ & 2012 & $\begin{array}{l}\text { Individual and social } \\
\text { meanings of mentoring. }\end{array}$ & NA & Literature & $\begin{array}{l}\text { Review, based on a } \\
\text { master thesis }\end{array}$ \\
\hline $\begin{array}{l}\text { Johnson, P., \& } \\
\text { Alamaa, S. }\end{array}$ & 2012 & $\begin{array}{l}\text { Mentoring as } \\
\text { sustainable school } \\
\text { development. }\end{array}$ & NA & Literature & Review \\
\hline $\begin{array}{l}\text { Jokikokko, K., } \\
\text { Uitto, M., } \\
\text { Deketelaere, } \\
\text { A., \& Estola, } \\
\text { E. }\end{array}$ & 2017 & $\begin{array}{l}\text { A beginning teacher in } \\
\text { emotionally intensive } \\
\text { micropolitical situations. }\end{array}$ & 1 teacher & $\begin{array}{l}3 \text { semi- } \\
\text { structured } \\
\text { interviews }\end{array}$ & $\begin{array}{l}\text { Narrative analysis, } \\
\text { holistic-content } \\
\text { approach }\end{array}$ \\
\hline $\begin{array}{l}\text { Jokinen, H., } \\
\text { Heikkinen, H., } \\
\text { \& Morberg, Å. }\end{array}$ & 2012 & $\begin{array}{l}\text { The induction phase as a } \\
\text { critical transition for } \\
\text { newly qualified } \\
\text { teachers. }\end{array}$ & $\begin{array}{l}29 \text { mentees, } \\
18 \text { mentors }\end{array}$ & $\begin{array}{l}\text { Questionnaires, } \\
\text { interviews, } \\
\text { reflective } \\
\text { journals }\end{array}$ & Thematic analysis \\
\hline $\begin{array}{l}\text { Kaunisto, S.- } \\
\text { L., Estola, E., } \\
\text { \& Leiman, M. }\end{array}$ & 2013 & $\begin{array}{l}\text { "I've Let Myself Get } \\
\text { Tired" - one teacher's } \\
\text { self-reflection process in } \\
\text { a peer group. }\end{array}$ & 11 teachers & $\begin{array}{l}\text { Observations } \\
\text { and transcripts } \\
\text { of video } \\
\text { recordings of } 16 \\
\text { meetings, } 70 \\
\text { pages in total. }\end{array}$ & $\begin{array}{l}\text { Dialogical } \\
\text { Sequence Analysis } \\
\text { (DSA) }\end{array}$ \\
\hline $\begin{array}{l}\text { Kaunisto, S.- } \\
\text { L., Estola, E., } \\
\text { \& Niemistö, } \\
\text { R. }\end{array}$ & 2012 & $\begin{array}{l}\text { The group as a context } \\
\text { for peer-group } \\
\text { mentoring. }\end{array}$ & NA & Literature & $\begin{array}{l}\text { Conceptual } \\
\text { analysis of } \\
\text { Tuckman's group } \\
\text { development } \\
\text { model in relation } \\
\text { to PGM }\end{array}$ \\
\hline $\begin{array}{l}\text { Kaunisto, S.- } \\
\text { L., Uitto, M., } \\
\text { Estola, E., \& } \\
\text { Syrjälä, L. }\end{array}$ & 2009 & $\begin{array}{l}\text { Ohjattu vertaisryhmä } \\
\text { haavoittuvuudesta } \\
\text { kertomisen paikkana. }\end{array}$ & 11 teachers & $\begin{array}{l}\text { Case study of } \\
\text { one mentoring } \\
\text { group }\end{array}$ & Narrative analysis \\
\hline $\begin{array}{l}\text { Kemmis, S., \& } \\
\text { Heikkinen, H. }\end{array}$ & 2012 & $\begin{array}{l}\text { Future perspectives: } \\
\text { Peer-group mentoring } \\
\text { and international } \\
\text { practices for teacher } \\
\text { development. }\end{array}$ & NA & Literature & $\begin{array}{l}\text { Conceptual } \\
\text { analysis: } \\
\text { Application of the } \\
\text { theory of ecologies } \\
\text { of practices to } \\
\text { mentoring }\end{array}$ \\
\hline
\end{tabular}




\begin{tabular}{|c|c|c|c|c|c|}
\hline $\begin{array}{l}\text { Kemmis, S., } \\
\text { Heikkinen, H., } \\
\text { Fransson, G., } \\
\text { Aspfors, J., \& } \\
\text { Edwards- } \\
\text { Groves, C. }\end{array}$ & 2014 & $\begin{array}{l}\text { Mentoring of new } \\
\text { teachers as a contested } \\
\text { practice: Supervision, } \\
\text { support and } \\
\text { collaborative self- } \\
\text { development }\end{array}$ & NA & $\begin{array}{l}\text { empirical } \\
\text { cases. Field } \\
\text { notes, } \\
\text { transcripts of } \\
\text { interviews } \\
\text { (including focus } \\
\text { groups) and } \\
\text { written, audio } \\
\text { and video } \\
\text { records of } \\
\text { observations of } \\
\text { mentoring } \\
\text { sessions. } \\
\text { Documents } \\
\text { collected in each } \\
\text { country: policy } \\
\text { documents, } \\
\text { reviews of } \\
\text { national } \\
\text { research } \\
\text { literature, } \\
\text { teachers' } \\
\text { reflections and } \\
\text { other texts. }\end{array}$ & $\begin{array}{l}\text { Multiple case study } \\
\text { approach }\end{array}$ \\
\hline $\begin{array}{l}\text { Kiviniemi, U., } \\
\text { Heikkinen, H., } \\
\text { Tynjälä, P., \& } \\
\text { Martin, A. }\end{array}$ & In review & $\begin{array}{l}\text { Running a hybrid: } \\
\text { Mingling in-service and } \\
\text { pre-service teachers in } \\
\text { peer-mentoring groups }\end{array}$ & 8 teachers & $\begin{array}{l}88 \text { pages of } \\
\text { transcripts } \\
\text { based on } \\
\text { interviews }\end{array}$ & Thematic analysis \\
\hline $\begin{array}{l}\text { Korhonen, H., } \\
\text { Heikkinen, H., } \\
\text { Kiviniemi, U., } \\
\text { \& Tynjälä, P. }\end{array}$ & 2017 & $\begin{array}{l}\text { Student teachers' } \\
\text { experiences of } \\
\text { participating in mixed } \\
\text { peer mentoring groups } \\
\text { of in-service and pre- } \\
\text { service teachers in } \\
\text { Finland. }\end{array}$ & $\begin{array}{l}19 \text { student } \\
\text { teachers }\end{array}$ & $\begin{array}{l}\text { Written } \\
\text { reflective } \\
\text { reports }\end{array}$ & $\begin{array}{l}\text { Phenomenographic } \\
\text { analysis }\end{array}$ \\
\hline $\begin{array}{l}\text { Lahdenmaa, } \\
\text { M., \& } \\
\text { Heikkinen, H. }\end{array}$ & 2012 & $\begin{array}{l}\text { Experiences of peer- } \\
\text { group mentoring in } \\
\text { homogenous and } \\
\text { heterogenous groups. }\end{array}$ & $\begin{array}{l}2 \text { groups, } 13 \\
\text { participants }\end{array}$ & $\begin{array}{l}\text { Focus group } \\
\text { interviews }\end{array}$ & $\begin{array}{l}\text { Comparative } \\
\text { qualitative analysis }\end{array}$ \\
\hline $\begin{array}{l}\text { Lassila, E. T., } \\
\text { Jokikokko, K., } \\
\text { Uitto, M., \& } \\
\text { Estola, E. }\end{array}$ & 2017 & $\begin{array}{l}\text { The challenges to } \\
\text { discussing emotionally } \\
\text { loaded stories in Finnish } \\
\text { teacher education. }\end{array}$ & 10 participants & $\begin{array}{l}6 \text { video- } \\
\text { recorded } \\
\text { sessions, diaries } \\
\text { of } 10 \\
\text { participants, } 1 \\
\text { later written } \\
\text { reflections }\end{array}$ & Narrative analysis \\
\hline Mäki, P. & 2012 & $\begin{array}{l}\text { Diverse landscapes of } \\
\text { mentoring }\end{array}$ & $\begin{array}{l}8 \text { school } \\
\text { leaders, } 5\end{array}$ & Interviews & Content analysis \\
\hline
\end{tabular}




\begin{tabular}{|c|c|c|c|c|c|}
\hline & & & $\begin{array}{l}\text { school } \\
\text { assistants }\end{array}$ & & \\
\hline Nissilä, S.-P. & 2015 & $\begin{array}{l}\text { Designing and testing an } \\
\text { educational program for } \\
\text { professional } \\
\text { development in work } \\
\text { places: Sharing expertise } \\
\text { in teachers' peer group } \\
\text { mentoring. }\end{array}$ & 10 mentors & $\begin{array}{l}\text { Questionnaire, } \\
\text { structured and } \\
\text { open-ended } \\
\text { questions, and } \\
\text { free writing }\end{array}$ & $\begin{array}{l}\text { Qualitative content } \\
\text { analysis }\end{array}$ \\
\hline Nissilä, S.-P. & 2013 & $\begin{array}{l}\text { The vocational teacher's } \\
\text { changing role and } \\
\text { identity in changing } \\
\text { contexts. }\end{array}$ & NA & 5 studies & $\begin{array}{l}\text { Conceptual } \\
\text { analysis based on } \\
\text { five empirical } \\
\text { studies }\end{array}$ \\
\hline $\begin{array}{l}\text { Pasanen, H., } \\
\text { \& Alanko- } \\
\text { Turunen, M. }\end{array}$ & 2019 & $\begin{array}{l}\text { Vertaisuuden } \\
\text { tunnustaminen } \\
\text { esimiesorientaationa } \\
\text { Verme-koulutus jaettua } \\
\text { johtajuutta } \\
\text { kehittämässä }\end{array}$ & 13 participants & $\begin{array}{l}\text { Observations, } \\
\text { essays and } \\
\text { material } \\
\text { produced in } \\
\text { mentor training } \\
\text { by the } \\
\text { participants }\end{array}$ & $\begin{array}{l}\text { Critical close } \\
\text { reading (Griselda } \\
\text { Pollock) }\end{array}$ \\
\hline $\begin{array}{l}\text { Pennanen, } \\
\text { M., Bristol, L., } \\
\text { Wilkinson, J., } \\
\text { \& Heikkinen, } \\
\text { H. }\end{array}$ & 2016 & $\begin{array}{l}\text { What is } \\
\text { 'good'mentoring? } \\
\text { Understanding } \\
\text { mentoring practices of } \\
\text { teacher induction } \\
\text { through case studies of } \\
\text { Finland and Australia. }\end{array}$ & 30 participants & $\begin{array}{l}5 \text { focus group } \\
\text { interviews ( } 16 \\
\text { participants) and } \\
\text { fictional stories } \\
\text { from } 14 \text { mentors }\end{array}$ & $\begin{array}{l}\text { Two order analysis, } \\
\text { inductive and } \\
\text { abductive } \\
\text { approach }\end{array}$ \\
\hline $\begin{array}{l}\text { Pennanen, } \\
\text { M., } \\
\text { Heikkinen, H. } \\
\text { \& Tynjälä, P. }\end{array}$ & 2018 & $\begin{array}{l}\text { Virtues of mentors and } \\
\text { mentees in the Finnish } \\
\text { model of teachers' peer- } \\
\text { group mentoring. }\end{array}$ & 30 participants & $\begin{array}{l}5 \text { focus group } \\
\text { interviews ( } 16 \\
\text { participants) and } \\
\text { fictional stories } \\
\text { from } 14 \text { mentors }\end{array}$ & $\begin{array}{l}\text { Philosophical- } \\
\text { empirical inquiry, } \\
\text { thematical content } \\
\text { analysis and post- } \\
\text { modernist, } \\
\text { constructivist } \\
\text { narrative approach }\end{array}$ \\
\hline $\begin{array}{l}\text { Rajakaltio, H., } \\
\text { \& Syrjäläinen, } \\
\text { E. }\end{array}$ & 2012 & $\begin{array}{l}\text { Peer-group mentoring in } \\
\text { the context of } \\
\text { transforming local } \\
\text { administration. }\end{array}$ & 6 mentors & $\begin{array}{l}\text { Questionnaires } \\
\text { and focus group } \\
\text { interviews }\end{array}$ & Case study \\
\hline $\begin{array}{l}\text { Syrjälä, L., \& } \\
\text { Estola, E. }\end{array}$ & 2012 & Diversity of mentoring. & 21 participants & Narratives & Plotted dialogues \\
\hline $\begin{array}{l}\text { Teerikorpi, S., } \\
\text { \& Heikkinen, } \\
\text { H. }\end{array}$ & 2012 & Keys to success. & 25 participants & $\begin{array}{l}\text { Written fictional } \\
\text { stories }\end{array}$ & $\begin{array}{l}\text { Content analysis, } \\
\text { narrative approach }\end{array}$ \\
\hline $\begin{array}{l}\text { Tynjälä, P., \& } \\
\text { Heikkinen, H. }\end{array}$ & 2011 & $\begin{array}{l}\text { Beginning teachers' } \\
\text { transition from pre- } \\
\text { service education to } \\
\text { working life: Theoretical }\end{array}$ & NA & Literature & Review \\
\hline
\end{tabular}




\begin{tabular}{|c|c|c|c|c|c|}
\hline & & $\begin{array}{l}\text { perspectives and best } \\
\text { practices. }\end{array}$ & & & \\
\hline $\begin{array}{l}\text { Uitto, M., } \\
\text { Kaunisto, S-L., } \\
\text { Syrjälä, L. \& } \\
\text { Estola, E. }\end{array}$ & 2015 & $\begin{array}{l}\text { Silenced truths: } \\
\text { relational and emotional } \\
\text { dimensions of a } \\
\text { beginning teacher's } \\
\text { identity as part of the } \\
\text { micropolitical context of } \\
\text { school. }\end{array}$ & 11 teachers & $\begin{array}{l}\text { Transcribed data } \\
\text { based on video- } \\
\text { recordings of the } \\
\text { group meetings }\end{array}$ & Narrative approach \\
\hline $\begin{array}{l}\text { Uitto, M., } \\
\text { Kaunisto, S.- } \\
\text { L., } \\
\text { Kelchtermans, } \\
\text { G., \& Estola, } \\
\text { E. }\end{array}$ & 2016 & $\begin{array}{l}\text { Peer group as a meeting } \\
\text { place: reconstructions of } \\
\text { teachers' self- } \\
\text { understanding and the } \\
\text { presence of } \\
\text { vulnerability. }\end{array}$ & 11 teachers & Teachers' stories & $\begin{array}{l}\text { Narrative analysis, } \\
\text { Spector-Mersel } \\
\text { model }\end{array}$ \\
\hline $\begin{array}{l}\text { Välijärvi, J., \& } \\
\text { Heikkinen, H. }\end{array}$ & 2012 & $\begin{array}{l}\text { Peer-group mentoring } \\
\text { and the culture of } \\
\text { education in Finland. }\end{array}$ & NA & Literature & Review \\
\hline $\begin{array}{l}\text { Wittek, D., } \\
\text { Ruohotie- } \\
\text { Lyhty, M., \& } \\
\text { Heikkinen, H. }\end{array}$ & 2017 & $\begin{array}{l}\text { Mentoring im } \\
\text { Berufseinstieg von } \\
\text { Lehrpersonen - ein } \\
\text { bilateraler Vergleich } \\
\text { zwischen Deutschland } \\
\text { und Finnland }\end{array}$ & NA & Literature & Review \\
\hline
\end{tabular}

